Potravinarstvo Slovak Journal of Food Sciences vol. 14, 2020, p. 1066-1074

https://doi.org/10.5219/1394

Received: 31 May 2020. Accepted: 11 November 2020. Available online: 28 November 2020 at www.potravinarstvo.com (C) 2020 Potravinarstvo Slovak Journal of Food Sciences, License: CC BY 3.0

ISSN 1337-0960 (online)

\title{
PATIN (PANGASIUS HYPOPHTHALMUS) FISH PROTEIN CONCENTRATE ALTERS INSULIN-LIKE GROWTH FACTOR (IGF)-1 AND IGF BINDING PROTEIN (IGFBP)-3 LEVEL OF SPRAGUE DAWLEY NEONATE RATS- INDUCED MALNUTRITION
}

\author{
Annisa Zikra Abdullah, Samnil Astuti Fitri, Muflihatul Muniroh, Tri Winarni Agustini
}

\begin{abstract}
Malnutrition is caused by inadequate protein intake and affects growth factor. High protein from patin (Pangasius hypophthalmus) fish is a well-known protein source. This study aims to investigate the effect of patin fish protein concentrate (PFPC) in the IGF-1 and IGFBP-3 level of Sprague Dawley (SD) neonate rats-induced malnutrition. Thirty male SD neonate rats were divided randomly into five groups, namely normal control (K1), malnutrition control (K2), malnutrition with PFPC $13.26 \mathrm{mg} \cdot \mathrm{g}^{-1}$ body weight (BW)/day (X1), malnutrition with PFPC $19.89 \mathrm{mg} \cdot \mathrm{g}^{-1} \mathrm{BW} / \mathrm{d}$ (X2), and malnutrition with casein supplement $13.26 \mathrm{mg} \cdot \mathrm{g}^{-1} \mathrm{BW} / \mathrm{d}(\mathrm{X} 3)$. K1 received a standard diet, while the others received a low $8 \%$ protein diet (L8PD) since those were born until 21 days. The standard diet was refed for all groups during the intervention (14 days). IGF-1 and IGFBP-3 levels were measured by ELISA. Normal data were analyzed by using One-way ANOVA which then was followed by post-hoc Bonferroni. Meanwhile, the others were analyzed by Kruskal Wallis and followed by Mann-Whitney U-test. Spearman test was used for correlation. PFPC contained $81.07 \%$ of protein, $4.08 \%$ of fat, $7.24 \%$ of moisture, $2.77 \%$ of ash, and $4.83 \%$ of carbohydrate. These contents had affected the growth factor. As a result, in the PFPC intervention, IGF-1, and IGFBP-3 levels $(p<0.05)$ were decreased, while the controls were increased. The decreased values were shown in IGFBP-3 levels $(p<0.05)$ while the increase was shown in both controls. On the other hand, the increase in body weight was shown in all groups, including control ones. A strong correlation was found between IGF-1 and IGFBP-3. PFPC has additional value on repairing malnutrition that is the best dose in effecting IGF-1 dan IGFBP3 levels is $13.26 \mathrm{mg} \cdot \mathrm{g}^{-1} \mathrm{BW} / \mathrm{d}$.
\end{abstract}

Keywords: FPC; Malnutrition; IGF-1; IGFBP-3

\section{INTRODUCTION}

Malnutrition is generally caused by restricted dietary intakes and ended with poor linear growth even in early life (Kartini, 2019; Aheto, 2015). Globally, undernutrition conditions have been caused by the mortality of $30 \%$ of children (Blossner and De Onis, 2005). The prevalence is still high in some developing countries in South East Asia such as Indonesia (UNICEF, WHO, and World Bank Group, 2018).

Malnutrition is caused by a lack of nutrients intake, such as a protein restriction diet (Kartini, 2019; Saunders, 2011; Gibson, 2005). Malnutrition, especially in the golden age, can cause growth faltering, such as stunting. Besides is also has a reciprocal relationship with infections that lead to systemic inflammation (Bartz, 2014; Guerrant, 2008; Lunn, 2007). Consequently, this condition results in the disruption of the body's hormonal function, including disruption of growth hormone $(\mathrm{GH})$. Furthermore, the disruption also affects the role of $\mathrm{GH}$ in releasing growth- related substances in the hypothalamus-pituitary-GH axis interaction. Malnutrition will also affect the mechanism in producing IGF-1 and IGFBP-3, the binding protein which is the principle binding protein of IGF-1 (Deboer, 2017; Bartz, 2014).

IGF-1 and IGFBP-3 are produced in the liver. They have a function in mediating the protein metabolism and controlling the growth factors which are accumulated in somatic cells (Guntur and Rosen, 2013; Skottner, 2012; McDonald, 2007; Laron, 2001). Their production is a form of $\mathrm{GH}$ secretion and even shows a resistant condition (Misra, 2003; Hintz, 1978). Decreased IGF-1 values are shown in acute malnutrition, while IGFBP-3 in chronic one. Both of them have special functions in several metabolic conditions (Gupta, 2011; Hoppe, 2004). Several studies on subjects with severe acute malnutrition, even normal, showed a decrease (Kartini, 2019; Hoppe, 2004; Misra, 
2003). Consuming high protein intake can improve this condition especially the function of IGF-1 and IGFBP-3.

Fish protein concentrate is a product resulting from the relieving moisture and fat content. Bioactive compounds and peptide contained in fish have benefits to control growth (Kundam, 2018). Patin (Pangasius hypophthalmus), a freshwater fish, is a tropical fish that can live in many countries in Southeast Asia such as Indonesia. Many fisheries technologies can maintain and protect the fish protein from damaged, such as by making fish protein concentrate. The fish protein intervention studies are wellknown studies and affect many pre-clinical and clinical indications (Nobile, 2016). With $80 \%$ protein reaches of PFPC and has greater digestibility, amino acids from patin fish, especially lysine and leucine, are more absorbed by the body than other protein sources, such as meat and poultry protein (Pratama, 2018). Discussing the high protein study and its effect on linear growth and malnutrition, high protein intake has shown its effects in increasing IGF-1 in boys and increasing IGFBP-3 of premature infants (Hoppe, 2004; Smith, 1997). This study aims to investigate whether the intervention of patin fish protein concentrate affects the IGF-1 and IGFBP-3 levels of Sprague Dawley (SD) neonate rats-induced malnutrition.

\section{Scientific hypothesis}

There are various doses of patin fish protein concentrate that affect insulin-like growth factor (IGF)-1 and IGF binding protein (IGFBP)-3 levels of Sprague Dawley neonate rats-induced malnutrition.

\section{MATERIAL AND METHODOLOGY \\ Preparation of patin fish protein concentrate}

Patin fish were bought at fishpond in the Ambarawa subdistrict, Semarang Regency, Central Java Province, Indonesia. The selected patin fish as those that have a good condition as shown by fresh patin that has just been captured, weighs about 1 kilogram for one fish, has fresh flesh, has gills that are still red, the color does not change and odorless. Then the patin fish were filleted and cleaned. The filleted fish were ground using a food processor with the addition of salt $(0.5 \%)$ and $\mathrm{NaHCO}_{3}(1.5 \%)$. Next, fish pasta was steamed for 30 minutes. The steamed pasta was then pressed and extracted by $96 \%$ food-grade ethanol with a 3:1 patin ratio. The extraction was carried out twice to fully relieve the moisture and fat content. The extracted fish was then dried at a temperature of $40{ }^{\circ} \mathrm{C}$ and mixed until refined size (60 mesh). The PFPC was wrapped in foodgrade silica gel and stored in the bottle at $4{ }^{\circ} \mathrm{C}$ (AOAC International, 2006).

Table 1 Ingredient compositions (g/kg) of low 8\% protein diet (L8PD) fed to malnutritiomn-induced rats.

\begin{tabular}{lc}
\hline Ingredients & L8PD $(\mathrm{g})^{*}$ \\
\hline Casein purified high nitrogen & 80 \\
Corn starch & 780 \\
Cottonseed Oil & 100 \\
Salt mixture U.S.P XIV & 40 \\
Total & 1000 \\
\hline
\end{tabular}

Note: * L8PD for K2,X1,X2, and X3.

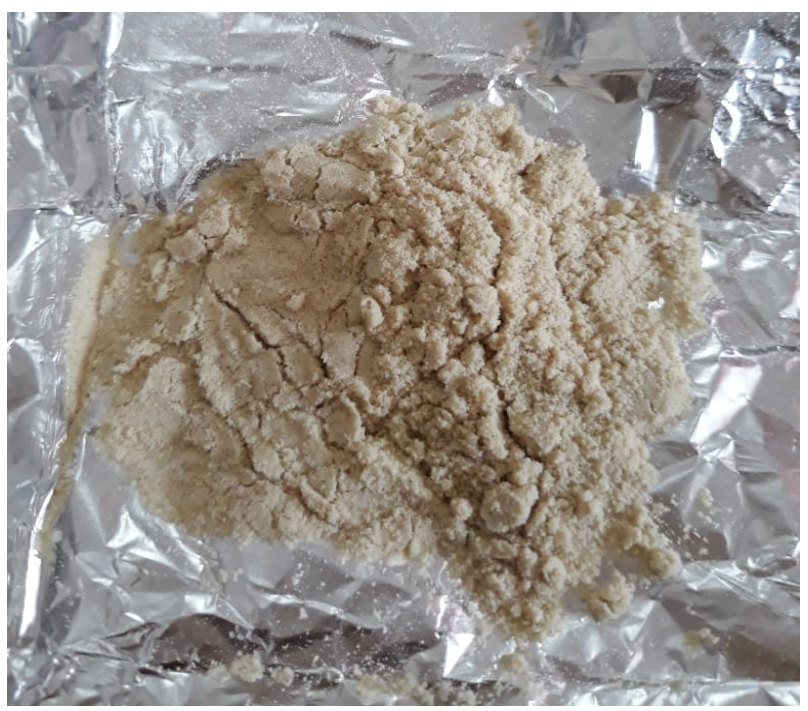

Figure 1 Patin Fish Protein Consentrate.

\section{Proximate analysis of patin fish protein concentrate}

The proximate analysis includes moisture, protein, ash, fat, and carbohydrate content (by difference) (AOAC, 2005).

\section{Research design and experimental-animals}

This research was a true-experiment study with a randomized pre-post test and has a control group design. The animal used was male Sprague Dawley rats, aged 21 days induced with a low $8 \%$ protein diet (L8PD), except health control. The acclimatization was held in the laboratory of Gadjah Mada University, Yogyakarta. The rats were placed in each group and numbered. They were placed at a regulated temperature $\left(21^{\circ} \mathrm{C}\right)$ and a clean cage. They were given ad-libitum water during the experiment. Animal care in the laboratory was carried out in accordance with the animal Laboratory Guideline from the Central Laboratory for Food and Nutrition Studies, Gadjah Mada University, Yogyakarta.

Thirty rats were divided into five groups, namely groups of normal control (K1), malnutrition control (K2), malnutrition with PFPC $13.26 \mathrm{mg} \cdot \mathrm{g}^{-1} \mathrm{BW} /$ day (X1), malnutrition with PFPC $19.89 \mathrm{mg} \cdot \mathrm{g}^{-1} \mathrm{BW} / \mathrm{d}$ (X2), and malnutrition with casein supplement $13.26 \mathrm{mg} . \mathrm{g}^{-1} \mathrm{BW} / \mathrm{d}$ (X3) (Wong, 2019). The malnutrition-condition was induced since 0 - 21 days old of neonate rat or through maternal L8PD (Table 1). After 3 days of acclimatization, the IGF-1 and IGFBP-3 were examined before the intervention. The intervention group was treated with the CMC-Na suspension method for 14 days. Body weight was measured every week since the animals were born until the interventions were ended. All of the groups were fed with Comfeed II standard-diet (CSD) during the intervention period. The blood sample was taken again at the end of the intervention through the retroorbital plexus. Blood samples were collected in a centrifugation tube and centrifuged 4000 rpm in 15 minutes. IGF-1 and IGFBP-3 levels were analyzed by ELISA (Kartini, 2019; Alishahi, 2013). 


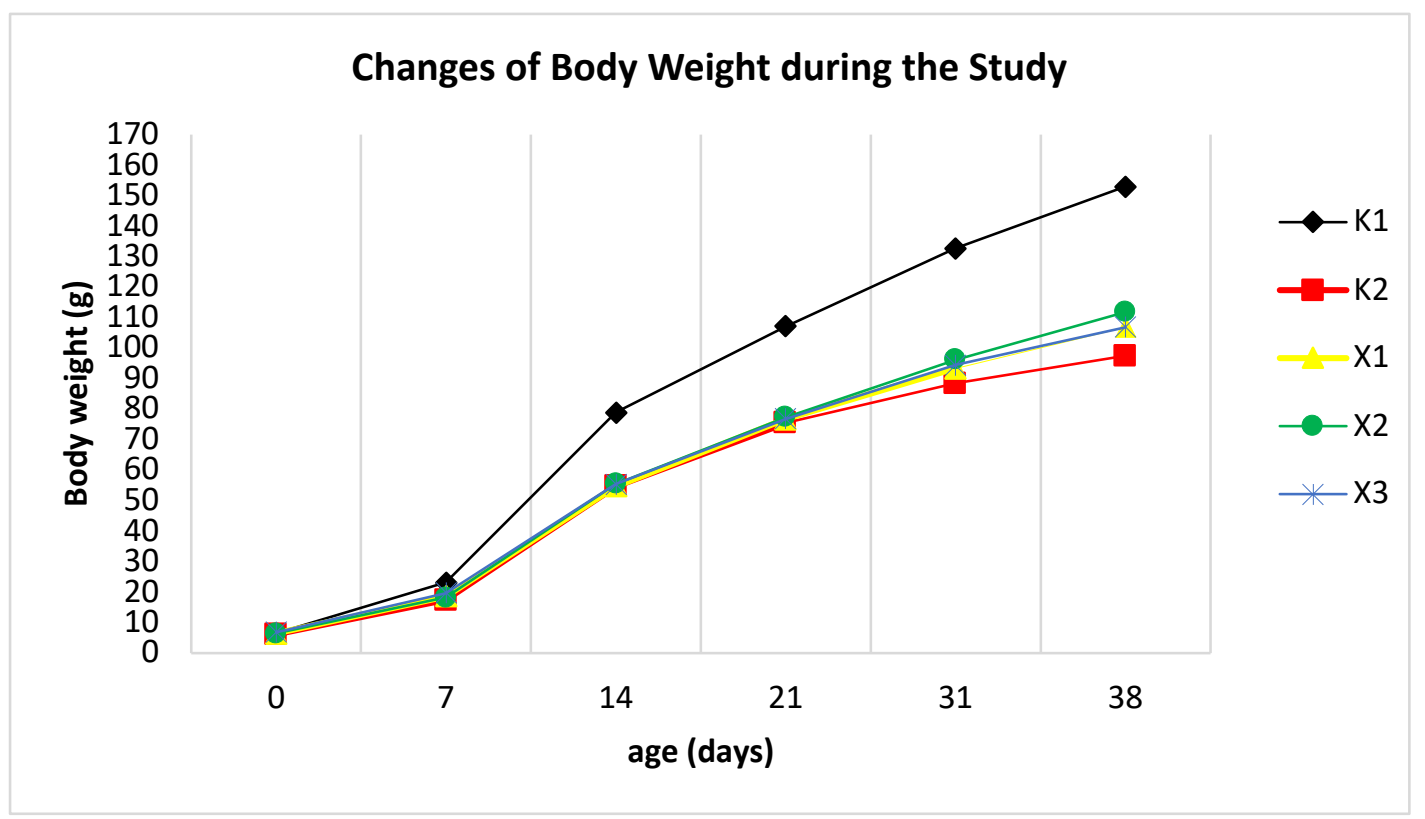

Figure 1 Changes of body weight of neonate rats during the study. Malnutrition was induced from day 0 to $21^{\text {st }}$ by giving low $8 \%$ protein diet (L8PD). PFPC intervention was started from day $24^{\text {th }}$ to $38^{\text {th }}$. Three days acclimatization was done from day $21^{\text {st }}$ to $24^{\text {th }}$.

\section{Ethical declaration:}

This study was approved by the Health Research Ethics Commission of the Faculty of Medicine Diponegoro University Semarang through ethical clearance No. 131/EC/H/KEPK/FK-UNDIP/X/2019.

\section{Statistical analysis}

Results were expressed as mean \pm SD (for normally distributed data), otherwise, it was expressed as median (min-max). Statistical difference was analyzed by using a one-way analysis of variance (ANOVA) followed by post hoc Bonferroni for normally distributed data, otherwise, the Kruskal-Wallis test followed by Mann-Whitney-U-test was used. The software used was SPSS software version 22 (SPSS Inc, Chicago, IL, USA). Spearman's correlative test was used to analyze the relationship between variables. Statistical analyses were done by the computer. The differences and correlations were considered significant at $p$-value $<0.05$ and $95 \%$ confidence intervals. The strength of the correlation was determined by the $r$-value.

\section{RESULTS AND DISCUSSION}

Related data about PFPC was shown as proximate analysis (Table 2). The other data about intervention processed was obtained from 30 Sprague Dawley-neonate rats, which were divided into each group consisting of 6 neonatal rats. The experimental animals used before intervention had an average body weight of 76.58 grams for the malnutrition group and 106.5 grams for the healthy control (data not shown).

Wilcoxon test carried out on the body weight before and after the intervention, showed that the intervention of PFPC increased the body weight in the all-treatment-group as shown in Table 3 and Table 4. Healthy-control-K1-group has experienced a significant increase in BW $(p=0.026)$. Statistically, the difference was also found on the pre-post intervention change $(\Delta)$ of neonate rats-BW among all groups (Kruskal Wallis test; $p=0.001$ ). Meanwhile MannWhitney U- test was also performed on two groups. The $\Delta$ neonate rats-BW of all-intervention-malnutrition-group were higher than malnutrition-control-K2-group and this result was significant (X1 and $\mathrm{X} 2$ had the same $p$-value; $p=0.004)$. The $\Delta$-neonate rats-BW of the X1-group was not different from the X3-group $(p=0.868)$. This finding demonstrated that PFPC can increase body weight which is higher in malnutrition neonate rats. Besides, this finding also showed that the ability of PFPC in dose $13.26 \mathrm{mg} \cdot \mathrm{g}^{-1}$ $\mathrm{BW} / \mathrm{d}$ in increasing body weight of malnutrition neonate rats has the same ability obtained from the casein supplement. The difference in body weight obtained during the study was shown in Figure 1.

The IGF-1 levels decrease at the end of the intervention, and significantly different $(p=0.028$ for $\mathrm{X} 1$ and $\mathrm{X} 2$, $p=0.027$ for X3; Table 4), while K2-group experienced a significant increase IGF-1 level $(p=0.027)$. The pre-postintervention-change $(\Delta)$ of IGF-1 levels was significantly different among five-groups (Kruskal Wallis test; $p=$ 0.001). Meanwhile, the $\Delta$-IGF-1-levels of all-interventionmalnutrition-group were different compared to malnutrition-control-K2-group (X1, X2, and X3 had the same $p$-value; Mann-Whitney U-test, $p=0.004)$. But, in suppressing of IGF-1 between all-malnutrition-treatedgroup, statistical analysis showed that the $\Delta$ IGF-1 in X1group was not different from X2 $(p=0.055)$ and X3-group $(p=0.054)$. This finding indicated that the ability of PFPC in dose $13.26 \mathrm{mg} . \mathrm{g}^{-1} \mathrm{BW} / \mathrm{d}$ was not different from the PFPC in dose $19.89 \mathrm{mg} \cdot \mathrm{g}^{-1} \mathrm{BW} / \mathrm{d}$ and the given of casein supplement. 
Table 2 Proximate analysis of PFPC.

\begin{tabular}{lc}
\hline Nutrient Content & $\%$ \\
\hline Moisture & $7.24 \pm 0.35$ \\
Ash & $2.77 \pm 0.07$ \\
Protein & $81.07 \pm 0.56$ \\
Fat & $4.08 \pm 0.18$ \\
Carbohydrate & $4.83 \pm 0.30$ \\
\hline
\end{tabular}

Note: * L8PD for K2,X1,X2, and X3.

Table 3 Statistical analysis of body weigth, IGF-1 and IGFBP-3 (control groups).

\begin{tabular}{|c|c|c|c|c|c|c|c|c|}
\hline \multirow{2}{*}{ Variables } & \multicolumn{4}{|c|}{$\mathrm{K} 1$} & \multicolumn{4}{|c|}{$\mathrm{K} 2$} \\
\hline & Pre & Post & $p^{a}$ & $\Delta$ & Pre & Post & $p^{a}$ & $\Delta$ \\
\hline$\overline{\mathrm{BW}}$ & $\begin{array}{c}106.5 \\
(104-112)\end{array}$ & $\begin{array}{c}152.5 \\
(149-158)\end{array}$ & $\frac{p}{0.026}$ & $\begin{array}{c}48 \\
(38-53)\end{array}$ & $\begin{array}{c}75.50 \\
(70-81)\end{array}$ & $\begin{array}{c}98.5 \\
(92-101)\end{array}$ & 0.026 & $\begin{array}{c}22.00 \\
(20.00-23,00)\end{array}$ \\
\hline IGF-1 & $\begin{array}{c}41.32 \\
(39.77-42.53)\end{array}$ & $\begin{array}{c}42.35 \\
(40.81-43.22)\end{array}$ & 0.026 & $\begin{array}{c}1.03 \\
(0.69-1.38)\end{array}$ & $\begin{array}{c}69.04 \\
(67.67-71.11)\end{array}$ & $\begin{array}{c}70.59 \\
(68.70-72.14)\end{array}$ & 0.027 & $\begin{array}{c}1.20 \\
(0.69-1.72)\end{array}$ \\
\hline IGFBP-3 & $40.89 \pm 2.69$ & $42.07 \pm 2.43$ & 0.004 & $1.17 \pm 0.57$ & $92.16 \pm 1.96$ & $94.53 \pm 2.23$ & 0.034 & $2.37 \pm 1.99$ \\
\hline
\end{tabular}

Note: ${ }^{a}$ p-values were obtained by Wilcoxon test (for BW and IGF-1), paired t test (for IGFBP-3); between pre-post intervention.

Table 4 Statistical analysis of body weigth, IGF-1 and IGFBP-3 (group with PFPC and casein intervention).

\begin{tabular}{|c|c|c|c|c|c|c|c|c|c|c|c|c|c|c|c|}
\hline \multirow[t]{2}{*}{ Variables } & \multicolumn{4}{|c|}{ P1 } & \multicolumn{4}{|c|}{ P2 } & \multicolumn{4}{|c|}{$\mathrm{P} 3$} & \multirow[t]{2}{*}{$\overline{p^{b}}$} & \multirow[t]{2}{*}{$p^{c}$} & \multirow[t]{2}{*}{$\overline{p^{d}}$} \\
\hline & Pre & Post & $p^{a}$ & $\Delta$ & Pre & Post & $p^{a}$ & $\Delta$ & Pre & Post & $p^{a}$ & $\Delta$ & & & \\
\hline BW & $\begin{array}{c}77 \\
(71-80)\end{array}$ & $\begin{array}{c}108 \\
(100-109)\end{array}$ & 0.027 & $\begin{array}{c}29.5 \\
(28-34)\end{array}$ & $\begin{array}{c}77 \\
(73-82)\end{array}$ & $\begin{array}{c}110 \\
(107-118)\end{array}$ & 0.027 & $\begin{array}{c}34.50 \\
(33-36)\end{array}$ & $\begin{array}{c}76.5 \\
(75-79)\end{array}$ & $\begin{array}{c}107 \\
(104-109)\end{array}$ & 0.026 & $\begin{array}{c}29.5 \\
(29-32)\end{array}$ & 0.005 & 0.001 & 0.001 \\
\hline IGF-1 & $\begin{array}{c}69.56 \\
(67.67- \\
99.35)\end{array}$ & $\begin{array}{c}53.72 \\
(52.51- \\
54.92)\end{array}$ & 0.028 & $\begin{array}{c}-16.01 \\
(-44.42- \\
13.77)\end{array}$ & $\begin{array}{c}68.70 \\
(66.29- \\
71.11)\end{array}$ & $\begin{array}{c}39.77 \\
(34.95- \\
41.15)\end{array}$ & 0.028 & $\begin{array}{c}-29.61 \\
(-33.75- \\
-25.14)\end{array}$ & $\begin{array}{c}68.53 \\
(66.63- \\
69.73)\end{array}$ & $\begin{array}{c}44.42 \\
(42.87- \\
45.63)\end{array}$ & 0.027 & $\begin{array}{c}-23.59 \\
(-25.83- \\
-23.07)\end{array}$ & 0.003 & 0.001 & 0.001 \\
\hline IGFBP-3 & $\begin{array}{l}92.56 \\
\pm 2.43 \\
\end{array}$ & $\begin{array}{l}66.23 \\
\pm 2.37\end{array}$ & 0.001 & $\begin{array}{l}-26.32 \\
\pm 3.23\end{array}$ & $\begin{array}{l}90.59 \\
\pm 2.65 \\
\end{array}$ & $\begin{array}{l}49.33 \\
\pm 1.23\end{array}$ & 0.001 & $\begin{array}{l}-41.26 \\
\pm 2.79\end{array}$ & $\begin{array}{l}92.71 \\
\pm 4.50 \\
\end{array}$ & $\begin{array}{l}46.56 \\
\pm 1.45\end{array}$ & 0.001 & $\begin{array}{l}-36.15 \\
\pm 3.60\end{array}$ & 0.001 & 0.001 & 0.001 \\
\hline
\end{tabular}

Note: ${ }^{a} p$-values were obtained by Wilcoxon test (for BW and IGF-1), paired t test (for IGFBP-3); between pre-post intervention. ${ }^{\mathrm{b}} p$-values were obtained by Kruskal Wallis test (for BW and IGF-1), One-way ANOVA test (for IGFBP-

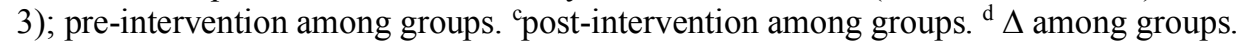

The IGFBP-3 levels experienced a decrease after the performance of the intervention. The levels were significantly different (X1, X2 and X3 had the same $p$-value; $p=0.001$; Table 4), while K2-group experienced a significant increase of IGFBP-3 level $(p=0.034)$. The prepost intervention-change $(\Delta)$ of the IGFBP-3 level was significantly different among the five groups (One-way ANOVA test; $p=0.001)$. The $\Delta$-IGFBP-3-levels of allintervention-malnutrition-group were different compared to malnutrition-control-K2-group (X1, X2, and X3 had the same $\mathrm{p}$-value; Post Hoc Bonferroni test, $p=0.001$ ).

The Spearman test on all data from all rats at the end of the study showed there was a very strong correlation that was found between the variables (IGF-1 and IGFBP-3). A very strong positive correlation was observed between IGF1 and IGFBP-3 $(r=0.861)$. This correlation was less weak before PFPC intervention began (data not shown).

Malnutrition can be ended with a linear growth disruption. Restriction of protein intake during the lactation period affects the disruption of long term linear growth (Cherala, 2006; Zambrano, 2005). We examined that the decreasing value of IGF-1 levels in the malnutrition-treatment-group after the intervention was caused by an inflammatory response. Systemic inflammation which occurs due to protein restriction during early life has not been repaired by early re-feeding.

Inflammation is a possible indication in the intervention group which is shown through the decreasing serum IGF-1 levels in neonatal rats. Indications of inflammation are thought to occur due to the placement of each group of neonate rats in one cage. The same result was also found in other previous studies showing the effect of interleukin 6 (IL-6) inflammatory biomarkers on IGF-1 descent. The decrease of IGF-1 is related to the mitogenic function of IGF-1 thereby inducing a decrease of its concentration in cell proliferation (Chen, 2009; Lann and LeRoith, 2008; Jenkins, 2000).

These indications of inflammation due to chronic malnutrition are also associated with $\mathrm{GH}$ resistance response, which modulates gluconeogenesis (Hawkes and Grimberg, 2015; Fazeli and Klibanski, 2014; Difedele, 2005; Turner, 1976). This condition can be attributed to the increase of $\mathrm{GH}$ and growth hormone receptor $(\mathrm{GHr})$ which modulates glucose homeostasis as indicated by an increase in body weight. However, in the mechanism of the endocrine system, the $\mathrm{GH}$ resistance condition causes a decrease in IGF-1 and IGFBP-3 concentrations (Martins, 2017; Liu, 2004; Hefferman, 2001). 
Other previous studies have assessed that serum IGF-1 levels can be assessed at four weeks of intervention. Meanwhile, this study assessed the IGF-1 in two weeks' intervention. This is also supported by the insignificant assessment of protein synthesis which ended with a disruption of metabolism especially the disruption of IGF-1 synthesis (Caregaro, 2001). The disruption of synthesis of the pituitary-GH-IGF1 axis is a major factor in the decrease of serum IGF-1 levels after re-feeding. The chronic malnutrition intake which has experienced by the subject suppresses the key components of IGF-1 and indicates impaired its production in the liver (Zamboni, 1996). This condition will provide IGF-1 negative feedback to the hypothalamus which results in an in increasing $\mathrm{GH}$ release. The decrease of IGF-1 in this study can also be related to the physiological response of IGF-1 which uses amino acids together with its pro-insulin structure, despite the subjects has been re-feed with high protein intake (Bonefeld and Moller, 2011). The other inhibitor that can be related to IGF-1 activity is adjusted with the IGFBP sub-type on an individual subject and the protease of the binding protein which is modulated by the level of their affinity (Kamycheva, 2012; Ferry, 1999).

Decreasing serum IGFBP-3 levels can cause disrupt IGF1 modulation. IGFBP-3 is the principal binding protein that modulates the action of IGF-1 as a growth factor. Disturbances that are caused by protein restriction and are not properly repaired realized that the pituitary-GH-IGF axis binding protein has a reciprocal effect (Bang, 1994). However, in this study, we found a negative relationship where there was a decrease in IGFBP-3 levels after the intervention. Previous studies that showed a decrease in IGFBP-3 proteolysis activity can make the binding protein of IGF-1 as a trigger of low levels of IGF-1 targets. The potential of IGFBP-3 in proteolysis depends on its posttranslational modification which has a great impact on IGF1 (Rosen and Yakar, 2020). Interestingly, the proteolysis mechanism of IGFBP-3 can occur with unknown protein in the extracellular matrix besides IGF-1. This condition exactly affects the decreasing IGF-1 level (Vorwerk, 1998; Bereket, 1995; Bang, 1994).

Proteolysis is the most possible mechanism in this study which has a function to reduce serum IGFBP-3 levels. Both levels of IGF-1 and IGFBP-3 which were decreased show that the mechanism most likely caused by proteolysis (Dauncey, 1993). Interventions in malnutrition children by re-feeding show a decrease in proteolytic activity, but restoring energy intake in the subjects (Zamboni, 1996). Decreasing the potency of proteolysis contributes to reducing the ability of IGFBP-3 to bind with IGF-1. The other reason is other competitors that can bind with IGF-1, such as IGF-1 receptors. These statements are related to IGFBP-3 which regulates IGF-1 bioactivity through nonspecific proteases (Pucilowska, 1993; Davenport, 1992). The action capability of this specific IGFBP-3 can even limit the bioavailability of free IGF-1 which is further regulated in the extracellular space if it is proteolysis must be done (Rosen and Yakar, 2020). This research proved that IGF-1 can be modulated by one of its main binding proteins (IGFBP-3), which is supported by acid-labile subunit to make a binary complex.

Interestingly, other growth factors besides IGF-1 and IGFPB-3 might be involved and affected the increasing body weight of neonate rats. These growth factors show the effect of suppression on IGF-1 and IGFBP-3 but support the mechanism of other growth biomarkers which is associated with the increasing body weight (Bereket, 1995; Bang, 1994). Excess of $\mathrm{GH}$ secretion, as the impact of its resistance condition, is stimulated by excess exactly of $\mathrm{GHr}$ secretion to support GH function. However, this condition reflects complete negative feedback as the result of decreasing in IGF-1 levels (Liu, 2004; Zamboni, 1996). The effect of increased GHr showed in previous studies modulates the increase in somatic growth (Liu, 2004; Hefferman, 2001). This hypothesis supports the results of this study. Deleting of GHr gene will affect decreasing body size (Liu, 2004). In this study, malnutrition neonate rats which were re-feed with supplementation of PFPC showed a significant growth acceleration compared to the healthy control.

Malnutrition condition, which was caused by cachexia symptoms and inflicted from malignancy response, also observed a similar indication. It was shown significantly by a specific combination of high-protein intake intervention which contained leucine (Van Norren, 2009). Increasing body weight is a positive effect from consuming highprotein intake which modulates the anabolism process in many cells and tissues is targeted by protein synthesis and the contribution of amino acids (Rogers and Harper, 1965).

The findings in protein intervention also improve clinical symptoms due to protein restriction. Other growth factors can affect the increase in body weight of malnutrition with re-feeding (Soliman, 1986). Increasing body weight can be driven by the anabolic response that is controlled by GH. The increase of GH secretion provides an alternative source of metabolism through fat mobilization and hepatic glucose production. This response has been reported in subjects without insulin resistance in basal conditions (Smith, 1981).

The increase of body weight which is indicated by increased $\mathrm{GH}$ is also associated with carbohydrate and fat homeostasis (Liu, 2004). Other studies conducted in children with marasmic and kwashiorkor showed lower serum IGF-1 levels in the marasmic group. This shows that energy intake takes the main place to process rather than the food protein process (Underwood, 1994; Dauncey, 1990). Another study also observed re-feeding carried out by returning the intake of rats to the standard diet could allow that the high intake of protein would not necessarily be effectively metabolized.

Furthermore, amino acid, especially lysine and leucine which are high in PFPC products could also change weight gain. We found in this study that the PFPC contained protein amounting $80 \%$ (Table 2) and the PFPC in a dose of $13.26 \mathrm{mg} . \mathrm{g}^{-1} \mathrm{BW} / \mathrm{d}$ did not have different effects from casein supplement in the same dose. These findings indicate that the ability of PFPC is no different from casein, which has purified high protein. It is expected that the PFPC has certain amino acids for gaining weight. Other studies also recognize that oral leucine supplementation stimulates muscle protein synthesis and is not dependent on insulin (Dardevet, 2002; Anthony, 2000). Once again, those findings supported this study that the mechanism of decreasing IGF-1 does not affect the increase of body weight because of its function associated with amino acids 
and pro-insulin (Bonefeld and Moller, 2011; Rinderknecht and Humbel, 1978). Although the protein concentration in this study product was high, even exceeding the concentration of similar products from the sThe isoleucine contin PFPC is higher than white fish protein hydrolysate (Windsor and Barlow, 1981). But, we did not further examine the amino acid content and their digestibility through in vitro studies.

The high protein concentration also supports the lipid and carbohydrate pool of neonate rats. Increased protein intake can affect the amount of lipids and carbohydrates stored in adipose tissue, especially white adipose tissue (WAT) (Zhang, 2019). As the largest cholesterol provider, WAT can be involved in cholesterol metabolism where cholesterol can increase to high-density lipoprotein (HDL) (Zhang, 2010). Besides WAT is also involved in the endocrine system which secretes protein factors, such as adipokines associated with energy regulation and inflammatory homeostasis (Rafols, 2014; Khovidhunkit, 2004). From the results of this study and existing theories, they indicate that protein intake and high-fat content of PFPC products affect the function of the adiposity system and lipoprotein. This mechanism puts an end to weight gain even though there is an indication of inflammation that is shown from the decrease in IGF-1 and IGFBP-3 levels.

Limitations of this study we do not examine other growth indicators on this intervention except the body weight. Discussing another growth factor, we also do not examine another related growth factor that can relate to and support the hypothesis of this study. Inflammation is not measured in this study, as expected to exist in chronic malnutrition neonate rats. The proteolytic, which can be the most possible involved mechanism in this study is also not concerned. We did not concern about the digestible amino acid of PFPC which can be compared to other products in case of body weight gain of malnutrition rats. Other biomarkers that relate to lipid metabolism also not a concern.

\section{CONCLUSION}

The administration of patin fish protein concentrate with various doses tested, significantly increased the body weight, but decreased IGF-1 and IGFBP-3 serum level of malnutrition-induced neonatal rats. The administration of patin fish protein concentrate with dose $13,26 \mathrm{mg} \cdot \mathrm{g}^{-1}$ body weight per day is the most effective dose in increasing body weight of malnutrition-induced neonatal rats.

\section{REFERENCES}

Aheto, J. M., Keegan, T. J., Taylor, B. M., Diggle, P. J. 2015. Childhood Malnutrition and Its Determinants among UnderFive Children in Ghana, Pediatric and Perinatal Epidemiology, Perinatal and Chilhood Outcome, vol. 29, no. 6, p. 552-561. https://doi.org/10.1111/ppe.12222

Alishahi, A., Roshan, V. D., Hedayyati, M. 2013. Pretreatment Effects of Regular Aerobic Training on the IGF System and Hepatotoxicity Induced by Doxorubicin in Rats, Asian Pacific Journal of Cancer Prevention, vol. 14, no. 12, p. 7427-7431. https://doi.org/10.7314/APJCP.2013.14.12.7427

Anthony, J. C., Yoshizawa, F., Anthony, T. G., Vary, T. C., Jefferson, L. S., Kimball, S. R. 2000. Leucine stimulates translation initiation in skeletal muscle of post-absortive rats via a rapamycin-sensitive pathwa, Journal of Nutrition, vol.
130

no.

10 p. https://doi.org/10.1093/jn/130.10.2413

AOAC 2005. Official Methods of Analysis of AOAC International, AOAC Inc., $18^{\text {th }}$ edn, Maryland, USA, AOAC International.

AOAC International 2006. 45.3.06 AOAC Official Method 991.29 True Protein Digestibility of Foods and Food Ingredients Rat Bioassay First Action 1991, Washington DC, USA.

Bang, P., Brismar, K., Rosenfeld, R. G. 1994. Increased proteolysis of insulin-like growth factor-binding protein-3 (IGFBP-3) in noninsulin deendent diabetes mellitus serum, with elevation of a 29-kilodalton ( $\mathrm{kDa}$ ) glycosylated IGFBP-3 fragment contained in the approxymately 130 -to $150-\mathrm{kDa}$ ternary complex, The journal of clinical endocrinology and metabolism, vol. 78, no. 5, p. 1119-1127. https://doi.org/10.1210/jcem.78.5.7513716

Bartz, S., Mody, A., Hornik, C., Bain, J., Muehlbauer, M., Kiyimba, T., Kiboneka, E., Stevens, R., St Peter, J. V., Newgard, C. B., Freemark, M. 2014. Severe acute malnutritio in childhood: hormonal and metabolic status at presentation, response to treatment, and predictors of mortality, The Journal of Clinical Endocrinology and Metabolism, Endocrine Research, vol. 99, no. 6, p. 2128-2137. https://doi.org/10.1210/jc.2013-4018

Bereket, A., Lang, C. H., Blethen, S. L., Fan, J., Frost, R. A., Wilson, T. A. 1995. Insulin-like growth factor binding protein3 proteolysis in children with insulin-dependent diabetes mellitus: a possible role for insulin in the regulation of IGFBP3 protease activity, The Journal of Clinical Endocrinology and Metabolism, vol. 80, no. 8, p. 2282-2288. https://doi.org/10.1210/jcem.80.8.7543110

Blossner, M., De Onis, M. 2005. Malnutrition : Quantifying the health impact at national and local levels, Environmental Burden of Disease, Geneva, World Health Organization Nutrition for Health Development Protection of the Human Environtment. Available https://apps.who.int/iris/bitstream/handle/10665/43120/92415 91870.pdf

Bonefeld, K., Moller, S. 2011. Insulin-like growth factor-I and the liver, Liver International, vol. 31, no. 7, p. 911-919. https://doi.org/10.1111/j.1478-3231.2010.02428.x

Caregaro, L., Favaro, A., Santonastaso, P., Alberino, F., De Pascoli, L., Nardi, M., Favaro, S., Gatta, A. 2001. Insulin-like growth factor 1 (IGF-1), a nutritional marker in patients with eating disorders, Clinical Nutrition, vol. 20, no. 3, p. 251-257. https://doi.org/10.1054/clnu.2001.0397

Chen, J., Stavro, P. M., Thompson, L. 2009. Dietary Flaxseed Inhibits Human Breast Cancer Growth and Metastasis and Downregulates Expression of Insulin-Like Growth Factor and Epidermal Growth Factor Receptor, Nutrition and Cancer, vol. 43, no. 2, p. $187-192$. https://doi.org/10.1207/S15327914NC432_9

Cherala, G., Shapiro, B. H., DAmello, A. P. 2006. Two Low Protein Diets Differentially Affect Food Consumption and Reproductive Performance in Pregnant and Lactating Rats and Long-Term Growth in Their Offspring, The Journal of Nutrition, Nutrient Requirements and Optimal Nutrition, vol. 136, no. 11, p. 2827-2833. https://doi.org/10.1093/jn/136.11.2827

Dardevet, D., Sornet, C., Bayle, G., Prugnaud, J., Pouyet, C., Grizard, J. 2002. Postprandial Stimulation of Muscle Protein Synthesis in Old Rats Can Be Restored by a LeucinSupplemented Meal, Oxford Academic, vol. 132, no. 1, p. 95100. https://doi.org/10.1093/jn/132.1.95 
Dauncey, M. J., Rudd, B. T., White, D. A., Shakespear, R. A. 1993. Regulation of insulin-like growth factor binding proteins in young growing animals by alteration of energy status, Growth Regulation, vol. 3, no. 3, p. 198-207. https://doi.org/7693100

Dauncey, M. J., Shakespear, R. A., Rudd, B. T., Ingram, D. L. 1990. Variations in somatomedin-C/insulin-like growth factor-I associated.with environmental temperature and nutrition, Hormonal dan Metabolic Research, vol. 22, no. 5, p. 261-264. https://doi.org/10.1055/s-2007-1004898

Davenport, M. L., Isley, W. L., Pucilowska, J. B., Pemberton, L. B., Lyman, B., Underwood, L. E., Clemmons, D. R. 1992. Insulin-like growth factor-binding protein-3 proteolysis is induced after elective surgery, The Journal of Clinical Endocrinology and Metabolism, vol. 75, no. 2, p. 590-595. https://doi.org/10.1210/jcem.75.2.1379257

Deboer, M. D., Scharf, R. J., Leite, A. M., Ferrer RN, A., Havt, A., Pinkerton, R., Lima, A. A., Guerrant, R. L. 2017. Systemic inflammation, growth factors, and linear growth in the setting of infection and malnutrition, Nutrition, Applied nutritional investigation, vol. 33, p. 248-253. http://dx.doi.org/10.1016/j.nut.2016.06.013

Difedele, L. M., He, J., Bonkowski, E. L., Han, X., Held, M. A., Bohan, A., Menon, R. K., Denson, L. A. 2005. Tumor necrosis factor alfa-blokade restores growth hormone signaling in Murine Collitis, Gastroenterology, Basic-Alimentary Tract, vol. 128, no. 5, p. 1278-1291. https://doi.org/10.1053/j.gastro.2005.02.003

Rafols, M. E. 2014. Adipose tissue: Cel heterogenity and functional diversity, Endocrinolia y Nutricion (English Edition), vol. 61, no. 2, p. 100-112. https://doi.org/10.1016/j.endoen.2014.02.001

Fazeli, P. K., Klibanski, A. 2014. Determinants of GH resistance in malnutrition, Journal of Endocrinologgy, GH resistance in malnutrition, vol. 220, no. 3, p. 57-65. https://doi.org/10.1430/JOE-13-0477

Ferry, R. J. Jr., Cerri, R. W., Cohen, P. 1999. Insulin-like growth factor binding proteins: new proteins, new functions, Homonal Research, vol. 51, p. 53-67. https://doi.org/10.1159/000023315

Gibson, R. S. 2005. Principles of Nutritional_Assessment, $2^{\text {nd }}$ edn, New York, NY : Oxford Press, 425 p. ISBN-13 978-0-19517169-3.

Guerrant, R. L., Oria, R. B., Moore, S. R., Oria, M. O., Lima, A. A. 2008. Malnutrition as an enteric infectious disease with long-term effects on child development, Nutrition Reviews, vol. 66, no. 9, p. 487-505. https://doi.org/10.1111/j.1753$\underline{4887.2008 .00082 . \mathrm{X}}$

Guntur, A. R., Rosen, C. 2013. IGF-1 regulation of key signaling pathways in bone, BoneKEy Reports, vol. 2, no. 437, p 1-6. https://doi.org/10.1038/bonekey.2013.171

Gupta, N., Lustig, R. H., Kohn, M. A., McCracken, M., Vittinghoff, E. 2011. Sex differences in statural growth impairment in Crohns disease: role of IGF-1, Inflammatory Bowel Diseases, vol. 17, no. 11, p. 2318-2325. https://doi.org/10.1002/ibd.21617

Hawkes, C.P., Grimberg, A. 2015. Insulin-like growth factor$\mathrm{I}$ is a marker for nutritional state, Pediatrics Endocrinology Review, vol. 13, no. 2, p. 499-511. https://doi.org/26841638

Hefferman, M., Summers, R. J., Thorburn, A., Ogru, E., Gianello, R., Jiang, W.-J., Frank M. Ng. 2001. The effects of human GH and its lipolytic fragment (AOD9604) on lipid metabolism following chronic treatment in obese mice and beta $_{3}$-AR knock-Out Mice, Endocrinology, vol. 142, no. 12, p. 5182-5189. https://doi.org/10.1210/endo.142.12.8522
Hintz, R. L., Suskind, R., Amatayakul, K., Thanangkul, O., Olson, R. 1978. Plasma Somatomedin and growth hormone values in childrean with protein-calorie malnutrition, The Journal of Pediatrics, vol. 92, no. 1, p. 153-156. https://doi.org/10.1016/S0022-3476(78)80099-7

Hoppe, C., Molgard, C., Juul, A., Michaelsen, K. F. 2004. High intakes of skimmed milk, but not meat, increase serum IGF-I and IGFBP-3 in eight-year-old boys, European Journal of Clinical Nutrition, original communication, vol. 58, p. 12111216. https://doi.org/10.1038/sj.ejcn.1601948

Jenkins, P. J., Frajese, V., Jones, A. M., Camacho-Hubner, C., Lowe, D. G., Fairclough, P. D., Chew, S. L., Grossman, A. B., Monson, J. P., Besser, G. M. 2000. Insulin-like growth factor I and the development of colorectal neoplasia in acromegaly, Journal of Endocrinology and Metabolism, vol. 85, no. $9, \quad$ p. $3218-3221$. https://doi.org/10.1210/jcem.85.9.6806

Kamycheva, E., Berg, V., Jorde, R. 2012. Insulin-like growth factor I, growth hormone, and insulin sensitivity: the efeects of a one year cholecalsiferol supplementation in middle-aged overweight and obese subjects, Endocrine, vol. 42, p. 412-418. https://doi.org/10.1007/s12020-012-9825-6

Kartini, A., Subagio, H. W., Hadisaputro, S., Kartasurya, M. I., Suhartono, S., Budiyono, B. 2019. Pesticide Exposure and Stunting among Children in Agricultural Areas, The International Journal of Occupational and Environtmental Medicine, vol. 10, no. 1, p. 17-29. https://doi.org/10.15171/ijoem.2019.1428

Khovidhunkit, W., Kim, M.-S., Memon, R. A., Shigenaga, J. K., Moser, A. H., Feingold, K. R., Grunfeld, C. 2004. Effects of infection and inflammation on lipid and lipoprotein metabolism: mechanisms and consequences to the host, Journal of Lipid Research, The Patogenesis of Atherosclerosis, vol. 45, p. 1169-1196. https://doi.org/DOI 10.1194/jlr.R300019-JLR200

Kundam, D. N., Acham, I. O., Girgih, A. T. 2018. Bioactive Compounds in Fish and Their Health Benefits, Asian Food Science Journal, vol. 4, no. 4, p. 1-14. https://doi.org/10.9734/AFSJ/2018/41803

Lann, D., LeRoith, D. 2008. The role of endocrine insulinlike growth factor-I and insulin in breast cancer, Journal Of Mammary Gland Biology Neoplasia, vol. 13, p. 371-379. https://doi.org/10.1007/s10911-008-9100-x

Laron, Z. 2001. Insulin-like growth factor 1 (IGF-1): a growth hormone. Journal of Clinical Pathology, vol. 54, no. 5, p. 311-316. https://doi.org/10.1136/mp.54.5.311

Liu, J.-L., Coschigano, K. T., Robertson, K., Lipsett, M., Guo, Y., Kopchick, J. J., Kumar, U., Liu, Y. L. 2004. Disruption of growth hormone receptor gene causes diminished pancreatic islet size and increased insulin sensitivity in mice, American Journal of Physiology and Metabolism, vol. 287, no. 3, p. 405-413. https://doi.org/10.1152/ajpendo.00423.2003

Lunn, P. G. 2007. The impact of infection and butrition on gut function and growth in childhood, Proceeding of Nutrition Society, vol. 59, no. 1, p. 147-154. https://doi.org/10.1017/S0029665100000173

Martins, V. J. B., de Alberqueuque, M. P., Sawaya, A. L. 2017. Endocrine changes in undernutrition metabolic programming, and nutritional recovery, Handbook of Famine, Starvation and Nutrient Deprivation https://doi.org/DOI 10.1007/978-3-319-40007-5 41-1

McDonald, T. J., Nijland, M. J., Nathanielsz, P. W. 2007. The insulin-like growth factor syste and the fetal brain: Effects of poor maternal nutrition, Reviews in Endocrinology and 
Metabolic Disorders, vol. 8, p. 71-84. https://doi.org/DOI 10.1007/s11154-007-9044-2

Misra, M., Miller, K. K., Bjornson, J., Hackman, A., Aggarwal, A., Chung, J., Ott, M., Herzog, D. B., Johnson, M. L., Klibanski, A. 2003. Alterations in growth hormon secretory dynamics in adolecent girls with anorexia nervosa and effects on bone metabolism, The Journal of Clinical Endocrinology \& Metabolism, vol. 88, no. 12, p. 5615-5623. https://doi.org/10.1210/jc.2003-030532

Nobile, V., Duclos, E., Michelotti, A., Bizzaro, G., Negro, M., Soisson, F. 2016. Supplementation with a fish protein hydrolysate (Micromesistius poutassou): effects on body weight, body composition, and CCK/GLP-1 secretion, Food and Nutrition Research, vol. 60, no. 1, p. 1-10. https://doi.org/10.3402/fnr.v60.29857

Pratama, R. I., Rostini, R., Rochima, E. 2018. Amino acids profile and volatile flavour compound of raw and steamed Patin catfish (Pangasius hypophthalmus) and narrow-barred Spanish Mackerel (Scomberomorus commerson), IOP Conference Series: Earth and Environtmental Science, vol. 116, p. 1-17. https://doi.org/10.1088/1755-1315/116/1/012056

Pucilowska, J. B., Davenport, M. L., Kabir, I., Underwood, L. E. 1993. The effect of dietary protein supplementation on insulin-like growth factors (IGFs) and IGF-binding proteins in children with shigellosis, The Journal of Clinical Endocrinology and Metabolism, vol. 77, no. 1, p. 1516-1521. https://doi.org/10.1210/jcem.77.6.7505287

Rinderknecht, E., Humbel, R. E. 1978. The amino acid sequence of human insulin-like growth factor I its structural homology with pro-insulin, The Journal of Biology Chemistry, vol. 253 , no. 8 , p. 2769-2776.

Rogers, Q. R., Harper, A. E. 1965. Amino acids diet and maximal growth in the rat, The Journal of Nutrition, vol. 87, no. 3, p. 267-273. https://doi.org/10.1093/jn/87.3.267

Rosen, C., Yakar, S. 2020. Growth hormone, insulin-like growth factor, and IGF binding proteins, Principle of Bone Biology, no. 42, p. 985-1015. https://doi.org/10.1016/B978-012-814841-9.00042-7

Saunders, J., Smith, T., Stroud, M. 2011. Malnutrition and Undernutrition, ELSEVIER, Undernutrition and Clinical Nutrition, vol. 39, no. 1, p. 45-50. https://doi.org/10.1016/j.mpmed.2018.12.012

Skottner, A. 2012. Biosynthesis of Growth Hormone and Insulin-Like Growth Factor-I and the Regulation of their Secretion., The Open Endocrinology Journal, vol. 6, p. 3-12. https://doi.org/10.2174/1874216501206010003

Smith, I. F., Latham, M. C, Azubuike, J. A., Butler, W. R., Phillips, L. S., Pond, W. G., Enwonwu, C. O. 1981. Blood plasma levels of cortisol, insulin, growth hormone and somatomedin in children with marasmus, kwashiorkor, and intermediate forms of protein energy malnutrition, Experimental Biology and Medicine, vol. 167, p. 607-611. https://doi.org/10.3181/00379727-167-41222

Smith, W. J., Underwood, L. E., Keyes, L., Clemmon, D. R. 1997. Use of Insulin-Like Growth Factor I (IGF-I) and IGF Binding Protein Measurements to Monitor Feeding of Premature Infants, Journal of Clinical Endocrinology and Metabolic, vol. 82, no. 12, p. 3982-3988. https://doi.org/10.1210/jcem.82.12.4452

Soliman, A. T., Hassan, A. E. H., Aref, M. K., Hintz, R. L., Rosenfeld, R. G., Rogol, A. D. 1986. Serum insulin-like growth factors I and II concentrations and growth hormone and insulin responses to arginine infusion in children with proteinenergy malnutrition before and after nutritional rehabilitation, Pediatrics Researchs, vol. 20, p. 1122-1130. https://doi.org/10.1203/00006450-198611000-00012
Turner, M. R., Reed, P. J., Munday, K. A. 1976. Action of growth hormone in vitro on the net uptake and incorporation into protein of amino acids in muscle from intact rabbits given protein-deficient diets, British Journal of Nutrition, vol. 35, no. 1, p. 1-10. https://doi.org/10.1079/BJN19760003

Underwood, L. E., Thissen, J. P., Lemozy, S., Ketelslegers, J. M., Clemmons, D. R. 1994. Hormonal and nutritional regulation of IGF-1 and Its Binding Proteins, Hormonal Research in Pediatrics, Session 1 Basic Aspects and Clinical Relevance of Binding Protein in the Action of GH and IGF-1, vol. 42, p. 145-151. https://doi.org/10.1159/000184187

UNICEF, WHO, World Bank Group 2018. Levels and trends in child malnutrition., UNICEF/WHO/World Bank Joint Child Malnutrition Estimatetes, Key Findings of the 2018 Edition, UNICEF, WHO, World Bank Group. Available at https://www.who.int/nutgrowthdb/2018-jme-brochure.pdf

Van Norren, K., Kegler, D., Argiles, J., Luiking, Y., Gorselink, M., Laviano, A., Arts, K., Faber, J., Jansen, H., van der Beek, E., van Helvoort, A. 2009. Dietary supplementation with a specific combination of high protein, leucine, and fish oil improves muscle function and daily activity in tumourbearing cachectic mice, Nature, vol. 100, p. 713-722. https://doi.org/10.1038/sj.bjc.6604905

Vorwerk, P., Yamanaka, Y., Spagnolli, A., Oh, Y., Rosenfeld, R. G. 1998. Insulin IGF binding by IGFBP-3 fragments derived from proteolysis, baculovirus expression and normal urine, Journal of Endocrinology and Metabolism, vol. 83, no. 4, p. $1392-1395$. https://doi.org/10.1210/jcem.83.4.4858

Windsor, M., Barlow, S. 1981. Introduction on fishery byproducts, Farnham, Surrey, England, Fishing News Book Ltd, Mollecular Nutrition Food Research, vol 26, no.6, p. 558. https://doi.org/10.1002/food.19820260619

Wong, C. P, Bray, T. M., Khanna, S. K. 2019. Growth, Bone Health, and Cognition: Nutritional Evaluation of a Sustainable Ocean-Based Advance Protein Powder (APP), Ecology Food and Nutrition, vol. 58, no. 2, p. 80-92. https://doi.org/10.1080/03670244.2019.1565759

Zamboni, G., Dufillot, D., Antoniazzi, F., Valentini, R., Gendrel, D., Tato, L. 1996. Growth Hormone-Binding Proteins and Insulin-Like Growth Factor-Binding Proteins in ProteinEnergy Malnutrition, before and after Nutritional Rehabilitation, Pediatrics Researchs, vol. 39, p. 410-414. https://doi.org/10.1203/00006450-199603000-00006

Zambrano, E., Rodriguez-Gonzales, G., Guzman, C., GarciaBecerra, R., Boeck, L., Diaz, L., Menjivar, M., Larrea, F., Nathanielsz, P. 2005. A maternal low protein diet during pregnancy and lactation in the rat impairs male reproductive development, The Physiological Society, vol. 563, no. 1, p. 265-284. https://doi.org/10.1113/jphysiol.2004.078543

Zhang, T., Chen, J., Tang, X., Luo, Q., Xu, D., Yu, B. 2019. Interaction between adipocytes and high-density lipoprotein: new insights into the mechanism of obesity-induced dyslipidemia and atherosclerosis, Lipid in Health and Disease, vol. 18, no. 223, p. 1170-1179. https://doi.org/10.1186/s12944019-1170-9

Zhang, Y., McGillicuddy, F. C., Hinkle, C. C., ONeill, S., Glick, J. M., Rothblat, G. H., Reilly, M. P. 2010. Adipocyte Modulation of High-Density Lipoprotein Cholesterol, Circulation, vol. 121, no. 11, p. 1347-1355. https://doi.org/10.1161/CIRCULATIONAHA.109.897330

\section{Acknowledgments:}

This research did not receive any specific grant from funding agencies in the public, commercial, or not-forprofit sectors. 


\section{Contact address:}

Annisa Zikra Abdullah, Diponegoro University, Faculty of Medicine, Department of Nutrition, Tembalang, Semarang Indonesia 50275, Tel: +6282169779197,

E-mail: annisaabdullah7@gmail.com

ORCID: https://orcid.org/0000-0002-0699-2448

Samnil Astuti Fitri, Diponegoro University, Faculty of Medicine, Department of Nutrition, Tembalang, Semarang Indonesia 50275, Tel: +6281266402421,

E-mail: samniel.artutime@gmail.com

ORCID: https://orcid.org/0000-0003-3091-6741

*Muflihatul Muniroh, Diponegoro University, Faculty of Medicine, Department of Physiology, Tembalang, Semarang Indonesia 50275, Tel: +62(24)76928010/1,

E-mail: muflihatul.muniroh@fk.undip.ac.id

ORCID: https://orcid.org/0000-0003-0020-6722
Tri Winarni Agustini, Diponegoro University, Faculty of Fisheries and Marine Science, Department of Fishery Products Technology, Tembalang, Semarang Indonesia 50275, Tel: +6281390653646,

E-mail: tagustini@lecturer.undip.ac.id

ORCID: https://orcid.org/0000-0003-0050-288X

Corresponding author: * 